\title{
Life Course Practices in Bronze Age Landscapes of East Central Sweden Beyond Divine Chiefs and Neodiffusionism
}

\author{
Susanne Thedéen
}

\begin{abstract}
This paper treats the ritual traditions and practices connected with burials in Bronze Age cairns and stone-settings in the province of Södermanland in east central Sweden. The author discusses how the social and ritual roles of the individuals buried in cairns can be intertwined with the characteristics of the landscape contexts where cairns have been placed. Particular attention is given to the meaning of a special combination of artefacts - a razor, a pair of tweezers, a double-stud and a knife blade - found in Bronze Age burial contexts. The author suggests that the razor and the other ritual equipment may have been used in connection with life course rituals.
\end{abstract}

Susanne Thedéen, Department of Archaeology, Stockholm University, SE10691 Stockholm, Sweden.

Key words: cairns, water landscape, razors, life course, east central Sweden, Bronze Age.

\section{INTRODUCTION}

The Bronze Age mounds of southern Scandinavia have attracted great interest over the years. Mounds have been interpreted as the individual graves of male chiefs and warriors, manifesting their power through rich grave goods (Kristiansen 1983, 1998, 1999; Larsson 1986, 2002; cf. Sørensen 1997), or they have been viewed as territorial markers (cf. Larsson 1986:103f). Less attention has, however, been given to cairns. Situated in what has been called the periphery, and with limited or no access to bronze and bronze artefacts, cairns have been regarded as the northern expression and imitation of mounds. In recent years the secondary use of mounds and cairns has been noticed (Jennbert 1993; Bolin 1999). My intention here is to focus on the ritual traditions and practices surrounding burials in Bronze Age cairns and stone-settings in the province of Södermanland in east central Sweden. Further, I will discuss how the social and ritual roles, which were ascribed to the individuals buried in cairns in the Bronze Age society, can be intertwined with the characteristics of the landscape contexts where cairns have been placed. Some of the issues I will touch upon are: What characterizes the landscape contexts of the cairns and stone-settings? Who are the persons buried in these monuments, and what roles did they have in the Bronze Age societies of Södermanland? In particular, bronze razors are discussed, and rather than viewing 
razors as toilet articles they are interpreted here as ritual equipment used in connection with life course rituals.

Gender research is now an established part of archaeology, but to a large extent there is still a lack of perspectives emphasizing age and the life course (for references and definition of the concept life course ( $\mathrm{Sw}$. levnadsbana) see Hauptman Wahlgren 2002:129f). Within the international archaeological debate, studies focusing on children, the life course and the social construction of age have lately attracted broader interest (e. g. Moore \& Scott 1997; Sofaer Derevenski 1997:485ff, 2000; Gilchrist 1999, 2000). Scandinavian archaeologists have so far mainly considered children and childhood (Lillehammer 1989; Johnsen \& Welinder 1995; Welinder 1998). Regarding the Bronze Age research, it is also important to visualise other genders and age categories than male power elites in order to give less distorted and narrow pictures of the Bronze Age societies. Further, Bronze Age research has recently experienced a trend of neodiffusionism, whereby travelling chiefs with divine power, alliances and common symbols among the aristocracies of Europe and the Middle East have been suggested (cf. Larsson 1993, 2002; Kristiansen 1998, 1999). I am more anxious for profound discussions and studies emphasizing variations between and within regions, and how different contexts of artefacts must be taken into consideration when interpreting the material culture.

\section{CAIRNS IN WATER LANDSCAPES}

In the province of Södermanland approximately 2,000 cairns and stone-settings have been registered according to the Registration of Ancient Monuments. Usually these monuments have yielded dates to the Bronze Age but occasionally to later prehistoric periods. Several Bronze Age scholars have pointed out that cairns quite often are positioned high in the landscape, with locations on hilltops and mountain ridges with spectacular views of the landscape (Hyenstrand 1966; Damell 1985:7; Johansen 1993:99f). A compilation of the heights above the shore-line for cairns and stone-settings gives, however, a somewhat different and more complex picture. The compilation comprises 737 cairns and stone-settings from nine parishes in eastern Södermanland with agglomerations of Bronze Age remains (cairns and stone-settings in cemeteries and below 15-20 meters above the shore-line have been excluded; Fig. 1). The majority of cairns and stone-settings, 83 per cent, appear in the interval 25-60 meters above the shore-line, while only 9 per cent have a location to the markedly high heights. However, all these cairns and stone-settings may not derive from the Bronze Age, as cairns were also erected during the Roman Iron Age and the Viking Age. The dates of bronze artefacts from excavated cairns show that not only the high locations were used for these monuments; also other places in the landscape, which have the character of boundaries, thresholds, passages or liminality, have been important to mark with cairns. 
Cairns and stone-settings meters above shore-line

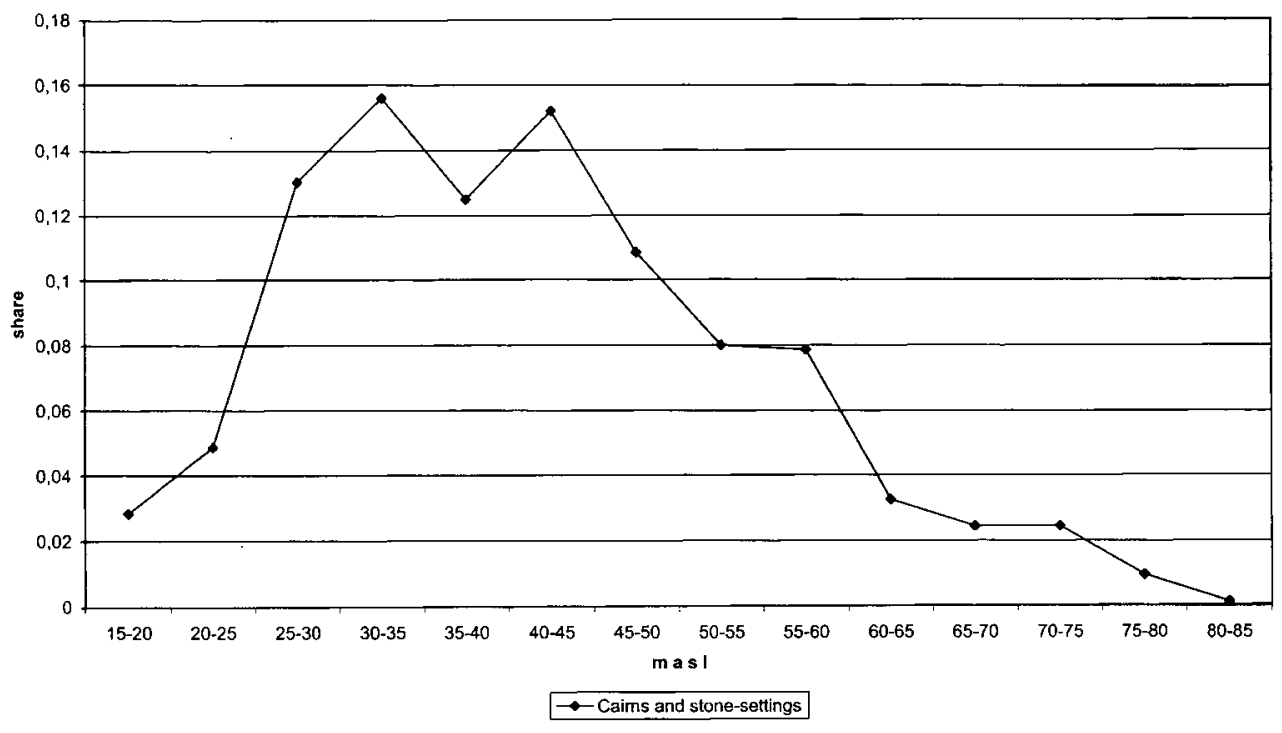

Fig. 1. The elevation of cairns and stone-settings above the shore-line in eastern Södermanland.

The common feature among these boundary places is that they have a reference to and allude to different kinds of water, not only open waters but also water contexts in connection with narrow water passages and shallow waters at fordable places, wetlands and bogs. In these contexts boundaries need not have the meaning of physical borders but may rather be considered as cosmological (Thedéen 1999:122, 2002a:129f). Three of the largest cairns in Södermanland, with a diameter exceeding 30 meters, can be mentioned here to illustrate the fact that cairns have been placed both high and low in the landscape but in relation to different water contexts. One of the cairns, located on Gullängsberget, RA $\ddot{A}$ 104, Tunaberg parish, has a classic position on a high mountain top, 65 meters above the shore-line, with a conspicuous view over the sea and the open water. Another cairn, Laxneröset, RAÄ 8, Gåsinge-Dillnäs parish, has instead been placed low in the landscape, on a point next to a narrow water passage in the lakes of Marvikarna only 20-25 meters above the shore-line. Finally, there is Björnlundaröset, RAÄ104, Björnlunda parish, which is positioned on an island, encircled by water, 55 meters above the shore-line. My opinion is that high mountain ridges were probably the first places where cairns were erected during the early Bronze Age. During the middle and late Bronze Age old cairns were rebuilt and reused at the same time as many new cairns were being erected.

Nevertheless I would like to emphasize the fact that cairns have also been erected in other landscape contexts than on mountain ridges and hilltops. These other contexts consist above all of points, capes, forelands, islands (cf. Bradley 1997) and narrow passages. A common feature among these places is that they 


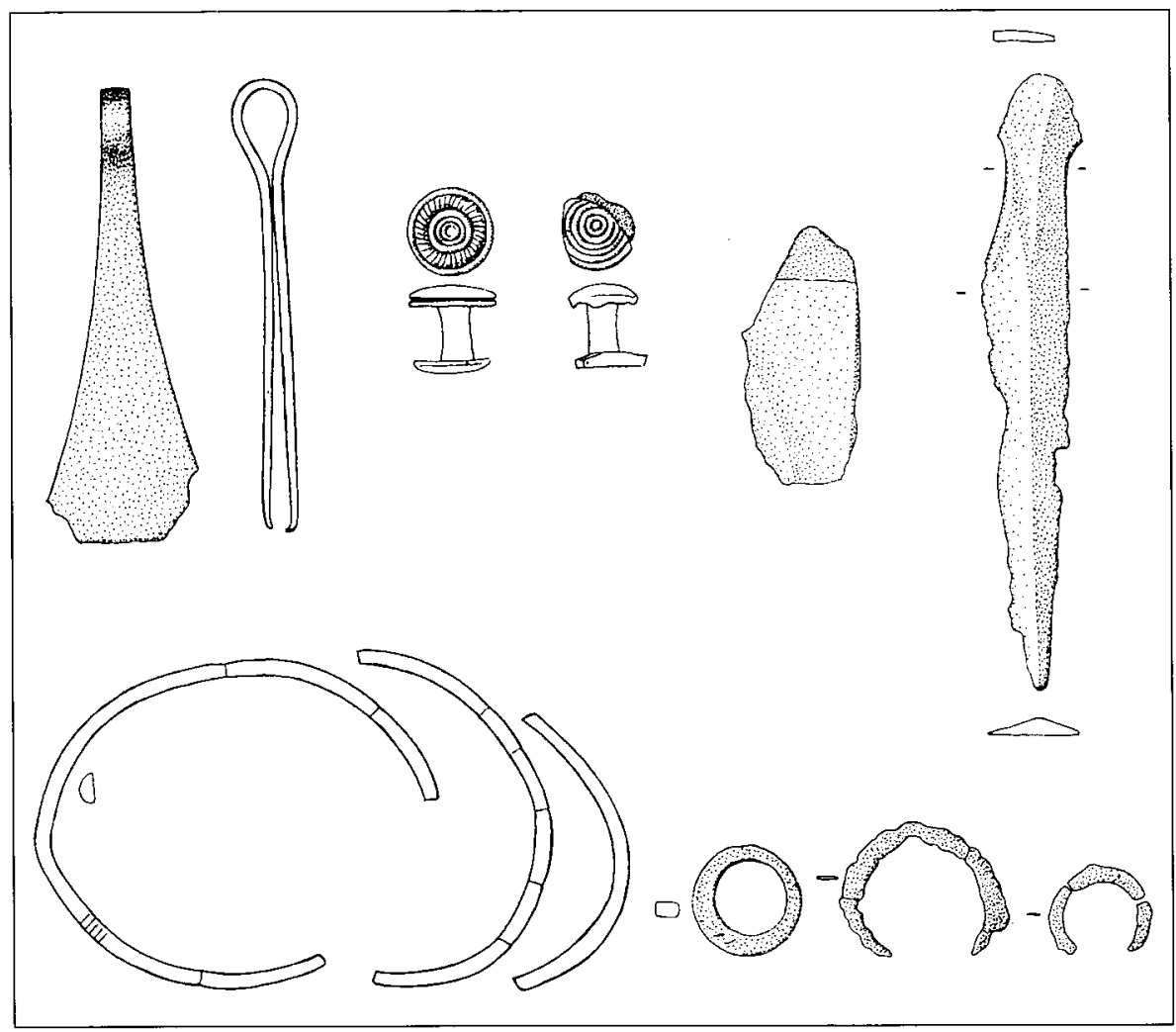

Fig. 2. Bronze artefacts from cairn RAÄ 33, Gärtuna, Östertälje parish (Elfstrand 1982:10).

all have a connection to water contexts and represent meeting points between different landscapes or various boundaries in the landscape: boundaries where water encounters rock, and where rock encounters sky. It seems reasonable to suggest that the relation between cairns and the shore-line can have other aspects than chronological ones. Besides, there is reason to believe that the purpose of building cairns may not only have been to provide a burial monument. In my opinion it is also possible to view cairns as important markers of significant places in the landscape with reference to cosmological worlds, where it was particularly important to mark boundaries and liminal places with monuments. Perhaps these thoughts can lead to other views of why some cairns contain complex, inner construction details and several remains of human bones whereas other cairns may be described in terms of "simple" stone heaps. I would in any case like to stress that water in general and different kinds of waters in particular had significance for the ritual world of the Bronze Age societies of east central Sweden.

As mentioned above, it is not uncommon that cairns contain inner construction details such as stone circles, hidden kerbs and wall constructions. In the province of Södermanland approximately 70 cairns and stone-settings from the Bronze Age have been excavated, among which 20 per cent have yielded intact or 


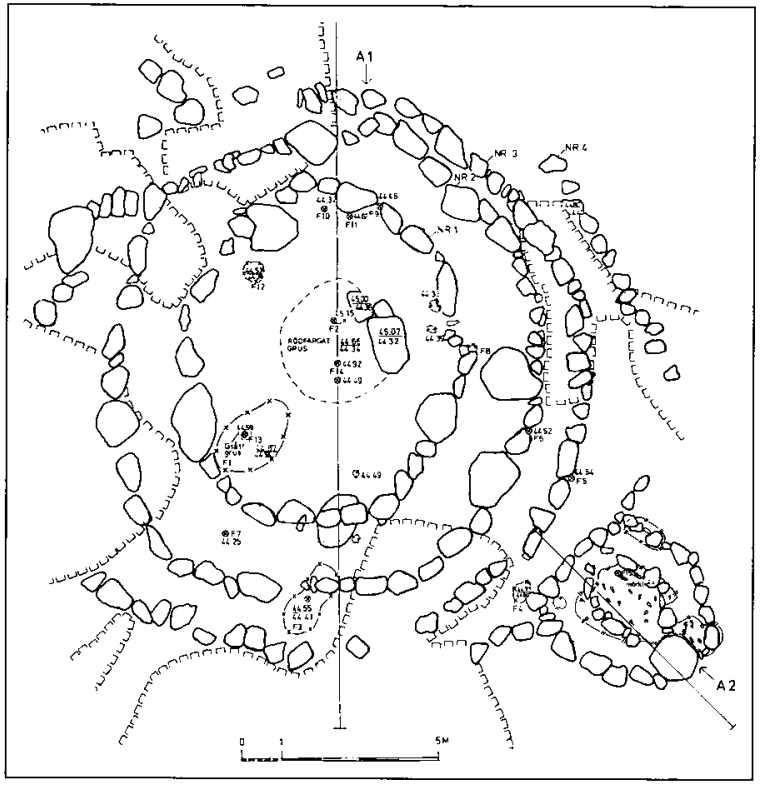

Fig. 3. Example of cairn with bronzes (in figure 2) in the southern rebuilt part (F3) (Elfstrand 1982:appendix).

fragmentary bronze artefacts. The most common bronze objects found in cairns are razors, tweezers, double-studs, knives, tutuli, belt hooks and various rings like finger-rings and armrings (Fig. 2).

Dates from cairns in Södermanland have proved to be a problematic issue. From period II only a few bronze artefacts have been found, but not in connection to inhumation burials but instead together with the remains of human cremated bones (Damell 1985:10f). In contrast to excavated cairns from northern Sweden, there is scanty evidence for centrally placed stone cists which could be indications of inhumation burials from period II (cf. Baudou 1968; Bolin 1999). On the contrary, in the Mälar valley, there are examples of Late Neolithic stone cists with skeletal remains from several individuals, the radiocarbon datings of which point towards continued burials also during the early part of the Bronze Age (Jaanusson \& Silvén 1962:38ff; Fagerlund och Hamilton 1995:75, 114; Andersson 2001:82). From period III and onwards the number of bronze objects found in cairns and stone-settings increases, with particular emphasis on the number of bronze artefacts during period IV and period $\mathrm{V}$ (Damell 1985). Another factor adding to this dating problem is that bronzes infrequently are found in the central parts of cairns. Rather bronzes appear to be associated with the rebuilding of cairns, and burials often occur in the southern part of cairns and stone-settings (see Hyenstrand 1966 with references; Fig.3) or are part of the last burial representing an abandonment of the monument.

There is also reason to comment on the absence of swords in cairns in Södermanland. There is only one clear example of a sword in a cairn, namely from RAÄ 20, Eriksberg, Botkyrka parish (Fig. 4). This sword, which is dated to period II, is surrounded by several obscure details. Firstly, it was not found in the central part of the cairn but in the eastern part. Secondly, the sword did neither lie together with cremated human bones, nor were there any signs of stone cist constructions or hollows in the rock that could indicate an inhumation burial. Thirdly, the sword was broken into three pieces with the various parts lying at a distance from each other (Hemmendorf 1978:23f). The sword appears more to have the character of an offering rather than of grave goods. 


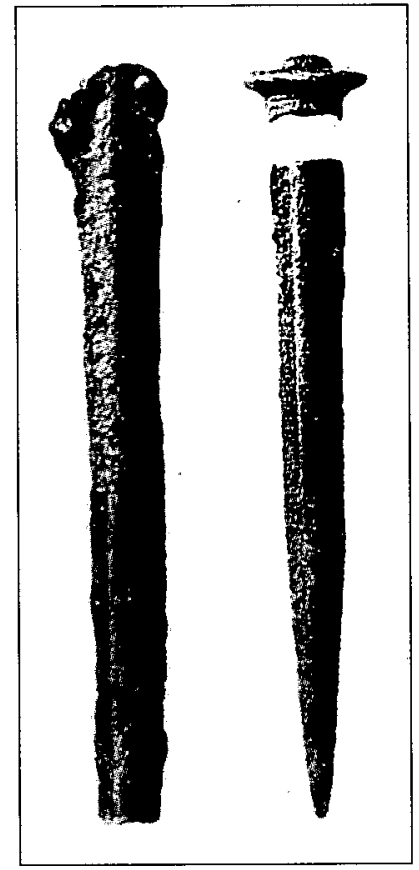

Fig. 4. Period II sword from cairn, RÄ̈ 20, Eriksberg. Botkyrka parish (Hemmendorf 1978:31).

The other six swords from Södermanland were found in contexts which might be interpreted as wetlands (both flowing deep waters and placid shallow waters, as well as bogs) during the Bronze Age. Four of the swords were single finds and two of them were found in hoard contexts (Wigren 1987:54ff). One of these swords, discovered already in 1836, in what was described as a man-made stone construction at Kyrkoherdebostället, Husby-Rekarne parish, could perhaps derive from a grave context. The sword has though been dated to the later part of the Bronze Age (Damell 1971:87; Wigren 1987:55). Compared to southern Scandinavia this sword material is scanty but I would nevertheless like to draw attention to the patterns that have been noticed. When comparing the patterns from the province of Södermanland with those from Uppland, Norrland and the eastern part of Östergötland it seems as if swords, but also daggers, in the latter provinces show the same pattern as in Södermanland. The swords and daggers were to a larger extent intended to be deposited in water contexts rather than in cairns or stone-settings (cf. Oldeberg 1974-1976; Bolin 1999:191-192; Hauptman-Wahlgren 2002:168f). There is only one clear example of a sword in a burial context (although from period 4), namely the famous and spectacular Håga mound, which in many respects shows signs of ambiguity and is often said to be an anomaly. In cairn contexts the closest evidence is a dagger from a stone-setting named Ulleråkers slott, Simtuna parish, Uppland (Drakenberg \& Gustawsson 1934). This discussion still leaves us with weak evidence of period II inhumation burials with swords in central graves. In my opinion, the absence of swords in cairns in the Mälar valley can be interpreted to mean that swords were not conceived of as personal attributes with reference to power and prestige. It appears instead as if swords had other meanings within the central Swedish region. Here swords might instead have been important as mutual objects. They possibly got their significance from the form and the bronze material in which they were created (cf. Jones 2002; Keates 2002). In any case, the connections to individuals or institutions which have been ascribed to swords in the societies of southern Scandinavia do not seem to be appropriate for the societies of central Sweden (cf. Bolin 1999:110ff). A comparable pattern, with swords in burials in some areas and swords in water contexts in neighbouring areas, has been discerned in Bronze Age Europe (Torbrügge 1971; Bradley 1990:99ff). It is possible that the deposits of swords in water contexts in central Sweden from both the earlier and later parts of the Bronze Age instead should be interpreted as 
a tradition with continuity from period I (cf. the sword from Bärbo, Södermanland, found in the Nyköping river, as well as the Bragby sword, Ramsta parish, Uppland and the sword from Norre, Heda parish, Östergötland, all found in bog contexts (Oldeberg 1974-76:348, 362, 290)). After this discussion on cairns in water landscapes I will view the cairns from an "inside" perspective and discuss what roles the individuals buried in cairns had in the Bronze Age societies of east middle Sweden. I will argue that liminal places in the landscape can be intertwined with liminal passages during a life course.

\section{RAZORS AS RITUAL EQUIPMENT}

In this context I would like to focus on a special combination of artefacts consisting of a razor, a pair of tweezers, a double-stud and a knife blade (Fig. 5). Ake Hyenstrand discussed these combinations from the Mälar valley in his licenciate dissertation from 1966. He pointed out that razors and tweezers have clear connections to grave contexts. They appear neither as single finds nor in hoards. Few razors have been found in settlement contexts. Therefore, Hyenstrand is of the opinion that razors did not have functional but rather religious purposes (Hyenstrand 1966:43). He suggests that razors and tweezers should be linked to mortuary rituals (Hyenstrand 1968:188). But razors have also been found in other monuments than cairns. There are examples from Uppland, Gotland and Småland where razors have been deposited in rectangular and ship-formed stone-settings (Drakenberg \& Gustawsson 1934; Pettersson 1982; Artelius 1996; Widholm 1998). Within these areas razors also occur in cairns. I would like to call these combinations of artefacts razor combinations. It can, of course, be discussed whether the concept razor is a suitable and relevant concept and if it is relevant to stress the razor and not another or all of the artefacts in the combinations. The razor is, however, the artefact in the combinations that has the most prominent appearance, both regarding the ornamentation and the form which indicates wide symbolic meanings.

An interesting aspect of the razor combinations in the Mälar valley is that swords do not occur together with them in burials with the exception of the Håga mound. With this background it is remarkable that the Håga mound has often been seen as an indication of the Bronze Age societies of

Fig. 5. Razor combination from stone-setting, RÄ̈ 22, Igelsta, Östertälje parish (Hyenstrand 1966). 
the Mälar valley, as being a mirror (although more pale and misty) of the social structure in southern Scandinavia. It appears more promising to take the regional characteristics as a point of departure if the aim is to study regional expressions. In the Mälar valley these expressions are burials oriented towards the south without swords but with razor combinations (Hyenstrand 1966). The cairn at Dragby in Skuttunge, Uppland, the stone-setting within henges at Odensala prästgård in Odensala, Uppland and the cairn at Igelsta in Östertälje, Södermanland, all have south-orientated razor combinations and therefore compose good examples of the societies and expressions of the region of central Sweden (Jaanusson \& Silvén 1962; Hyenstrand 1966; Olausson 1995). In Scania swords and razors are a more common combination. A compilation of razors in burial contexts in the work of Andreas Oldeberg (1974-76) shows that in 30 per cent of the graves with razors from the older Bronze Age, swords have also been found (19 out of 67).

Traditionally razors have been seen as an indication of male burials and been interpreted as functional, personal items, toilet articles, used in connection with shaving and hair cutting (Glob 1971; Jochenhövel 1971:245f). Swords, on the other hand, have also been interpreted as personal items but to a greater extent been associated with the role of chief, a member of the power elite, or the institution which these individuals represented in the Bronze Age society (cf. Larsson 1986; Kristiansen 1998 among others). I would argue that also razors can be connected with roles, but not roles related to political power or ritual institutions in the Bronze Age society. Instead I link razor combinations to individuals within the family/ kin who had esoteric knowledge and wisdom, certain skills of how to perform the ritual practices, and the ability to transform children, women and men - both the young and the old - through passages during their life course.

During the 1990s scholars have focused on razors as ritual expressions, and attention has been given to the elements of shape, design and ornamentation on the razors. Especially the ship symbolism of razors but also horses, birds, snakes and fishes have been noticed. This has led scholars to suggest that razors have strong ties to the ritual world of the Bronze Age (Kaul 1998, 1999). Flemming Kaul has, for example, proposed that the ornamentation on razors together with the direction of the ornamentation can be connected to ideas of how the ship, in composition with different animals (the fish, the horse and the snake, with the bird as mediator between different phases), is an expression of the worship of the sun in a cyclical world-view, where the sun disc is carried across the sky (Kaul 1998:262f; 1999:20f). The fish helps the ship during dawn, the horse helps the ship during the course of day, and the snake helps the ship during dusk.

Kristina Jennbert has suggested that razors and tweezers were part of the mortuary practices. Her view is that the individuals buried with razors could have held shamanistic positions in the Bronze Age society (Jennbert 1992). I agree with Jennbert that razors should be perceived as ritual objects. After all, it is not difficult to imagine a multitude of other occasions than shaving when the razor and the other objects in the combination were used in different practices, practices 
connected with the transformation of human bodies. There are examples from southern Scandinavia where razors and the other ritual equipment have been found in leather bags and wooden boxes (Svensson 1986:50f). These bags have, in addition to the ritual equipment, contained objects such as parts from animals, which strengthens the idea that razors, tweezers, double-studs and knives in combination should be interpreted as ritual objects. One example of such is a burial from period III at Hvidegaard in Lyngby on Zealand, Denmark, where a razor, a pair of tweezers, a knife and a fire-stone were found together with a snake's tail, a bird's claw and a jaw from a squirrel (Glob 1971; Carlsson 2001:35). It is interesting to note that two of these animals (the snake and the bird) are those that occur as a shape and ornamentation on razors.

Paul Treherne (1995) has also perceived razors as ritual objects, but he has instead connected the razor with preparations of the body to show the beauty of male warriors through shaving, hair cutting and cleaning both in life and in death. My interpretation of razors is based first of all on the view that the razor is not an object in isolation, but should rather be interpreted as one object among others where the razor was important. Secondly, I will argue that it is possible to connect these ritual objects not only to death, but also to other occasions or passages during a life course, and to more groups of people in the Bronze Age societies than only to men, such as children, women and old people.

\section{CONTEXTS OF RAZORS IN SÖDERMANLAND}

In the province of Södermanland there are fifteen complete or partial razor combinations that have been dated to the Bronze Age (Fig. 6). A complete combination consists of a razor, a pair of tweezers, a double-stud and a knife. Occasionally awls and flint fire-stones are also part of the ritual equipment. My criterion for a combination is that a razor must be represented. In one case (Säby, Salem parish), however, I have included a grave without a razor but with objects such as a pair of tweezers, a double-stud and a pin, which makes an interpretation as a razor combination probable. In two other cases (RÄ̈ 21:1, Igelsta, Östertälje parish and RAÄ 142, Lagersberg, Eskilstuna) I have included cairns containing bronze fragments as these have been interpreted as razors or knives. Most razor combinations have been found in Botkyrka and Östertälje parishes in the eastern part of Södermanland. These parishes have the largest number of excavated cairns. Some of the other combinations have been found in the area surrounding Eskilstuna, and two others in the south-eastern part of the province in the parishes of Bettna and Trosa-Vagnhärad. There are a number of common features that characterize the razor combinations, as well as some local variations between the eastern and the western part of Södermanland.

Starting with the landscape contexts, it can be noticed that all the cairns and stone-settings containing razor combinations are located at different kinds of boundaries, passages or liminal places in the landscape with reference to water contexts. They have been placed on mountain ridges and hilltops, islands in the 


\begin{tabular}{|c|c|c|c|c|c|}
\hline Socken, fastighet, raä nr & $\begin{array}{l}\text { Cairn/ } \\
\text { Stone-setting }\end{array}$ & $\begin{array}{l}\text { Single/ } \\
\text { cemetery }\end{array}$ & $\begin{array}{l}\text { Inhumation/ } \\
\text { cremation }\end{array}$ & Inner kerb & $\begin{array}{l}\text { Osteological } \\
\text { estimate } \\
\end{array}$ \\
\hline $\begin{array}{l}\text { Botkyrka, Eriksberg } \\
\text { RAÄ } 19\end{array}$ & C $18 \times 22 \mathrm{~m}$ & single & cremation & yes & woman \\
\hline $\begin{array}{l}\text { Botkyrka, Skarpbrunna } \\
\text { RAÄ } 87\end{array}$ & S $10 \times 10$ & single & cremation & yes & no \\
\hline $\begin{array}{l}\text { Salem, Säby } \\
\text { SHM } 25861\end{array}$ & $\mathrm{C}$ & single & cremation & no & no \\
\hline $\begin{array}{l}\text { Salem, Dånviken } \\
\text { SHM } 21397\end{array}$ & $\begin{array}{l}\text { Found on } \\
\text { a hilltop }\end{array}$ & - & - & - & - \\
\hline $\begin{array}{l}\text { Östertälje, Igelsta } \\
\text { RAÄ 21:1 }\end{array}$ & C $15 \times 15$ & single & cremation & yes & $\begin{array}{l}\text { woman } \\
\text { old }\end{array}$ \\
\hline $\begin{array}{l}\text { Östertälje, Igelsta } \\
\text { RAÄ22 }\end{array}$ & S $10-12$ & single & cremation & yes & $\begin{array}{l}\text { woman } \\
25-30\end{array}$ \\
\hline $\begin{array}{l}\text { Östetälje, Igelsta } \\
\text { RAÄ33 }\end{array}$ & C $15 \times 15$ & single & cremation & yes & no \\
\hline $\begin{array}{l}\text { Husby-Rekarne, Hållsta } \\
\text { RAÄ55 }\end{array}$ & & single & cremation & - & adult \\
\hline $\begin{array}{l}\text { Eskilstuna, Vilsta } \\
\text { RAÄ148 }\end{array}$ & $\mathrm{S} 10 \times 10$ & single & cremation & central block & no \\
\hline $\begin{array}{l}\text { Eskilstuna, Lagersberg } \\
\text { RAÄ142 }\end{array}$ & $\begin{array}{l}\text { Cairn-like S } \\
16 \times 16\end{array}$ & single & cremation & 3 blocks & no \\
\hline $\begin{array}{l}\text { Gillberga, Hyndevad } \\
\text { RAÄ127 }\end{array}$ & S $7,5 \times 8,5$ & $\begin{array}{l}\text { single } \\
\text { cemetery } 104 \\
\text { below }\end{array}$ & cremation & yes & adult \\
\hline $\begin{array}{l}\text { Eskilstuna, Åsby } \\
\text { RAÄ } 13\end{array}$ & $\begin{array}{l}\mathrm{S}(\mathrm{A} 30) 8 \times 8 \\
\mathrm{~S}(\mathrm{~A} 33) \\
5,5 \times 5,5\end{array}$ & $\begin{array}{l}\text { cemetery } \\
\text { cemetery }\end{array}$ & $\begin{array}{l}\text { cremation } \\
\text { cremation }\end{array}$ & $\begin{array}{l}\text { central block } \\
\text { central block }\end{array}$ & $\begin{array}{l}\text { adult } \\
\text { woman? } \\
\text { man } \\
\text { juv-adult }\end{array}$ \\
\hline $\begin{array}{l}\text { Bettna, Åkerö } \\
\text { RAÄ } 278\end{array}$ & S $9 \times 9$ & single & - & - & no \\
\hline $\begin{array}{l}\text { Trosa-Vagnhärad, Trosa- } \\
\text { Alby 4:6 RAÄ90 }\end{array}$ & C $17 \times 17$ & single & cremation & no & no \\
\hline
\end{tabular}

Fig. 6. Razor combinations from Södermanland. 


\begin{tabular}{|c|c|c|c|c|c|c|c|}
\hline Razor & Double-stud & Tweezer & Knife & Other & Orientation & Date & Reference \\
\hline $\mathrm{x}$ & $\mathrm{x}$ & & & & $\mathrm{S}$ & per3 & Hemmendorf 1978 \\
\hline \multirow[t]{2}{*}{$\mathrm{x}$} & & & & & $\mathrm{S}$ & per3-4 & Jaanusson 1973 \\
\hline & $\mathrm{x}$ & $x$ & & pin & $?$ & per5 & Hyenstrand 1966 \\
\hline $\mathrm{x}$ & & & $\mathrm{x}$ & & - & per4-5 & Oldeberg 1938 \\
\hline \multicolumn{3}{|c|}{ two blade fragments } & & & SV & $?$ & Hyenstrand 1966 \\
\hline $\mathrm{x}$ & $\mathrm{x}$ & $\mathrm{x}$ & $\mathrm{x}$ & fire-stone & $S$ & per4-5 & Hyenstrand 1966 \\
\hline $\mathrm{x}$ & $2 \mathrm{x}$ & $\mathrm{x}$ & $\mathrm{x}$ & & $\mathrm{S}$ & per4-5 & Elfstrand 1982 \\
\hline $\mathrm{x}$ & $\mathrm{x}$ & & & tutulus & $?$ & per3 & Damell 1971 \\
\hline $\mathrm{x}$ & $\mathrm{x}$ & & & & $\mathrm{S}$ & per4-5 & Bergengren 1968 \\
\hline \multicolumn{4}{|c|}{4 fragments probably a razor } & & $\mathrm{S}$ & late BA & Bergengren 1968 \\
\hline $\mathrm{x}$ & & & & & $\mathrm{S}$ & late $\mathrm{BA}$ & Damell 1971 \\
\hline $\mathrm{x}$ & & & & pin, awl & $\mathrm{S}$ & per6 & Damell 1971 \\
\hline $\mathrm{x}$ & & & & pin & SV & per6 & Damell 1971 \\
\hline $\mathrm{x}$ & & & & & central & per3-4 & SHM 32470 \\
\hline $\mathrm{x}$ & & & & fire stone & central & per3 & Appelgren 1993 \\
\hline
\end{tabular}


wetlands, narrow water passages surrounded by high mountains where rivers cross the landscape, or points and capes with a spectacular view over open water. As an example I can mention the cairn with a razor combination shown in Fig. 2 (RAÄ 33, Gärtuna, Östertälje parish), which was placed on an island in what was then wetlands, 44 meters above the shore-line (Elfstrand 1982:13f). Another example within the same landscape is the stone-setting with a razor combination on the Igelsta hill (RÄ̈ 22, Igelsta, Östertälje parish). This stone-setting had been placed on a cape with a wide view overlooking a water passage, 62 meters above the shore-line (Hyenstrand 1966:4, 12). The razor combinations in both these monuments have been dated to period IV-V.

Turning to the interior of the constructions, one common feature is that all burials with razor combinations, with one exception, contain cremated human bones. There do not seem to be any clear examples of razors in contexts which could be interpreted as inhumation burials. The dates of the razors range from period III to period VI. In Södermanland, the tradition with razor combinations has its origin during period III, and three out of fifteen combinations have been dated to this period. From the transition between period III and period IV there are two more combinations. A culmination is reached during periods IV and V with as many as seven razor combinations. From period VI there are two razors. From the latest part of the Bronze Age there is an indication of changes in the ritual practices. Razors appear instead to be deposited in cemeteries, sometimes together with pins, but not in the combinations that characterize earlier periods (Damell 1971:32f).

Another common feature, with only two exceptions, is the orientation of the razor combinations to the south or south-west in the cairns and stone-settings. This should possibly be given cosmological explanations. Most razor combinations from Uppland also have an orientation to the south, although there are some examples of centrally placed razors (e.g. the Dragby cairn with a pair of tweezers and a double-stud in the central area, as well as four razor combinations orientated south and south-west (Jaanusson \& Silvén 1962:5ff); and the stonesetting in the enclosure at Odensala prästgård, with a razor centrally placed and with burials with a southern orientation (Olausson 1995:69f)). Secondary graves in Bronze Age barrows in southern Scandinavia also often have been placed in the southern parts of the monument.

There are osteological analyses of the cremated bones in seven of fifteen combinations. In all seven cases the cremated bones have been found to derive from what we today would call adults who were buried together with the razor combinations. The osteological examinations have yielded age categories ranging from juvenilis to maturus. Regarding the osteological sexing, the analyses have revealed four women and one man, which show that both men and women could be buried with razors. As razors traditionally have been connected to male burials it is important to note the possibility of women being buried with razors. The material from Uppland also indicates that both men and women could be buried with razors, although most of the analyses point to men (Hyenstrand 1966:38f). 
Some of the razors from Södermanland have ornamentation, but only one has traces of animal ornamentation. This razor is dated to period $V$, based on the end of the handle which is in the form of a spiral snake, and it was found together with a fragment of a knife on a mountain at Dånviken in Salem parish. The objects probably derive from a grave. The ornamentation consists of two bird figures, one duck-like bird animal and one larger bird, perhaps a swan or a stork (Oldeberg 1938:117f; Fig.7).

A local variation is apparent between different parts of the province of Södermanland. In the east, for example, the razors have been found in large cairns or stone-settings built directly on the rock. The depositions or burials also appear to be connected with a rebuilding of the cairn or represent in some cases the last burial, accordingly an abandonment of the monument. Further, a common feature of the eastern razor combinations is that they all have been found in cairns that have inner construction details such as stone walls, stone circles and hidden kerbs. In western Södermanland, on the other hand, razor combinations seem to occur not only in cairns but also in cemetery contexts. In the three cases where this occurs it has, however, been suggested that the stone-settings with razors are the earliest constructions in the cemetery (Bergengren 1968:3f; Damell 1971). Razors in cemetery contexts and together with pins are an indication of a date to the latest part of the Bronze Age, possibly period VI (Damell 1971:32f). Perhaps it is possible to discern changes in the traditions with razor combinations. The fact that the pair of tweezers and the double-stud are excluded and the pin is added could be interpreted as changing ritual traditions, whereby the pin may indicate that tattooing had become part of the ritual practices. Yet another local difference is that in western Södermanland the razors occur in stone-settings with a central block, whereas this grave form is not represented among the razor combinations in eastern Södermanland.

\section{RITUAL PRACTICES AND METAMORPHOSES DURING THE LIFE COURSE}

I interpret the individuals buried with razor combinations in cairns as persons who passed on the ritual traditions and who had ritual wisdom and secret knowledge of how to perform ritual practices in connection with different passage rituals and liminal conditions during the life course. These life course rituals include cultural constructions of both biological and social passages. I imagine that these persons took on this role on certain occasions in connection with different

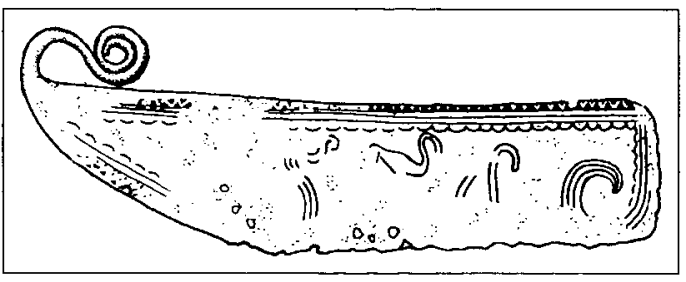

Fig. 7. Razor from Dånviken, Salem parish (Oldeberg 1938:120). 
passage rituals, transformations and metamorphoses during the life course of people. More than one person probably held these ritual roles and at different kinds of rituals.

But who/which persons could take on ritual roles? It is my opinion that special qualities as well as esoteric and secret knowledge were required. These persons possibly had charismatic, mystical powers, not connected to physical strength but rather to mental abilities, and knowledge of the hidden and the way in which the passage rituals should be performed. Anthropological studies of kinship-based societies show that it is especially in connection with initiation rituals that family or kin members, such as a brother or sister, an uncle or aunt, take on the role of ritual specialist (e.g. Lutkehaus \& Roscoe 1995). The analyses of the 15 razor combinations from cairns and stone-settings in Södermanland show that both men and women of variable age could be buried with this combination of artefacts. The possibility of achieving a ritual role was probably not connected to biological sex but more so to age. No children have been buried with these artefacts. Rather, it seems as if the persons buried with a razor combination must be at least osteological juveniles.

Another aspect to bring up is that osteologists have pointed out that the bone material from razor combinations indicates persons with a thin and slender frame, but still of the male sex. As examples I can mention three of the most spectacular Bronze Age graves known so far: The first is the Håga mound in Uppland, containing a sword, two razors, two tweezers, three double-studs and one brooch. The osteologist, Professor Classon, noted that, "the bones derive from an individual with an average height with a rather graceful frame and there is nothing to prevent the bones from being female". The bones were osteologically estimated to derive from a middle-aged person (Almgren 1905:31). The second example is a mound from Scania, Valleberga 6:7, a secondary grave with a sword, two brooches, a razor combination and a fire-stone among several other artefacts. The osteologist, Ove Persson, have estimated the bones to derive from a man between the ages of 40 and 55 who had a graceful and slender frame (Strömberg 1975:30ff). Finally, the third example is the Lugnaro mound in Halland, an urn burial with a southern orientation in relation to the centrally placed ship-setting. The urn contained the remains of a miniature dagger, a pair of tweezers and an awl together with cremated bones from a human and a sheep/goat. The bones have been osteologically estimated (by Professor N-G Gejvall) as a woman(?) under the age of 25 but an adult (Lundborg 1972:17f, 131). These examples show that, in contexts where other aspects of the human body than biological sex are of importance, different physical characteristics from osteological observations may be of interest (Hodder 1997:75f). Thus, it is possible to imagine more than one alternative when interpreting which persons the razor combinations represent. One line of interpretation is that both men and women could be buried with razor combinations. Another alternative is that only men were buried with them, but men with special physical characteristics (the slender and graceful ones). Finally there is a third alternative, 
where biological sex was not of importance. Possibly the persons were instead seen as androgynous.

Studies of different passage rituals during people's life course have long been of great importance within anthropological research. Most archaeologists refer to the cultural anthropologists Arnold van Gennep (1960) and Victor Turner (1969). Van Gennep has suggested that different rites of passage have a tripartite structure which he calls separation - transition - incorporation or alternatively preliminal liminal-postliminal. In addition to these concepts I would like to take as a point of departure the works of the social anthropologist Bruce Lincoln (1991) and especially his concepts for the meanings of the ritual process in connection with passage rituals. In his book Emerging from the Crystalis Lincoln focuses on the differences between initiation rituals for girls and boys. His opinion is that the concepts of van Gennep and Turner have been worked out primarily in connection with studies of male initiations. Consequently, they do not give a fair picture of how female initiation should be understood in the societies studied. Lincoln therefore chooses to work with the concepts of enclosure - metamorphosis/ magnification - emergence. These concepts also appeal to me as they have a depth and contain a meaning-perspective as well as putting focus on the purpose of the rituals and how they are experienced, not by the society in general, but by those who participate in the passage rituals.

Anthropological research shows that liminal phases and metamorphoses during life course rituals can in many cases go on for a considerable period of time, which often comprises several stages or phases before one is viewed as transformed. Among, for example, the Yangoru Boiken in Melanesia there are six phases, of which some are separated between the sexes and others are joint for a man and a woman living as a couple: first menstruation, first intercourse, first child birth, the kwali and the pana grades, and the suwer grade at the initiation of the first son. A couple is viewed as fully initiated when their youngest daughter has participated in her first menstruation ritual (Roscoe 1995:56f).

Passage rituals comprise not only the individual, for example the newborn, the initiate or the dead. Rather, the whole family or kin can be part of the metamorphosis and may during the liminal phase be kept outside society through different kinds of spatial restrictions or bodily markings (e.g. Lutkehaus \& Roscoe 1995). It is common that special clothing is worn (or none at all), that one is not allowed to eat at all or only particular kinds of foods; and that one is only allowed to stay at certain places in special houses or enclosures. Furthermore it is common with a wide range of bodily manipulations, pain and violence through cutting and pricking, as well as manipulation through bodily substances. These ritual practices have been interpreted as societies' ways of controlling different kinds of taboos and of what is perceived as ritually pure or impure (cf. Douglas 1997). Several anthropological examples show that ritual violence and different manipulations with the body and bodily substances is a common feature, especially in connection with initiation rituals (La Fontaine 1985; Lincoln 1991; Lutkehaus 
1995:18; Joyce 2000). The initiates must pass a number of ordeals connected with bodily manipulations such as shaving, circumcision, tattooing as well as other means of scarring and wounding the body. The bodily violence and mutilation are often interpreted as a link in the testing and marking of the initiate's new social role.

\section{PASSING THROUGH TIME IN SPACE}

Drawing inspiration from these anthropological observations, in my opinion there is a number of different ways and occasions when the artefacts in the razor combinations can have been used in the ritual practices. Some suggestions related to different phases of the life course are the cutting off of the navel-string, causing bleeding from different parts of the body, shaving not only the beard but also other types of body hair, removal of skin during ritual purifications, circumcision, and cleaning of dead bodies before the funeral pyre and interment. The pair of tweezers may be an indication of taboos on substances that could not be touched. An interpretation of the razor as a ritual object is underlined by the associations expressed by both the shape and the ornamentation of the razor. There are, as mentioned above, fishes, horses, snakes, birds and incised ships on razors. Alternatively the razor can be shaped like a ship. A change can be seen over time whereby the handles of older razors (period II-III) end in the head of a horse while the handles of younger razors are shaped like a snake or a spiral (period IV-V).

I would like to consider another aspect of the shape and ornamentation of the razors besides the one related to the cycle of the sun and daily rhythms as suggested by Flemming Kaul (1998:257f; 1999:20f). In my opinion it is possible to link the shape and ornamentation of razors to changes in social roles during the life course. A common feature of the ornamentation is that all the phenomena depicted on the razors allude to and give associations to movements and means of journeying, which are of a non-human kind. There is the swiftness of the horse; the snake, coiling and evoking movement without any legs; birds flying in the sky; fishes swimming in the water; and ships afloat on the water and moving across the sea. The ship holds in many respects a special position. The ship forms the basis which the other animals relate to and occur in combination with. These animal phenomena can be considered as metaphors for different ways of journeying in mind or moving from one phase in life to another. The fish, with associations to the water, the movable and life-giving, may then in analogy with Kaul's argumentation be considered as a metaphor for the birth of a child and the beginning of the life course; the horse may represent initiation where fertility, power and swiftness is important to mark out; while the snake can be seen as a metaphor for rituals towards the end of the life course or even for the funeral rituals when the dead is buried among the stiff and dead stone. If this argumentation is linked to Kaul's ideas about the ornamentation on razors mirroring the daily rhythm of the sun, it can be suggested that razors with fish ornamentation can be linked to the cutting 
off of the navel-string; razors with horse symbolism can be linked to initiation rituals; and finally razors with snakes can mirror preparations of the dead body connected with funeral rituals.

As mentioned earlier, the razors and the other artefacts in the combination are usually not found in "settlement" contexts. Rather they are linked to burial contexts. There are, however, some examples of razors that were found on settlements. One such example is from the Hallunda settlement, Botkyrka parish in the province of Södermanland, known for its bronze-casting activities. Anders Carlsson (2001:51) has recently pointed out that Hallunda is a special place where bronze-casting is intertwined with burials and heaps of fire-cracked stones. In RAÄ 69 - the part of the Hallunda settlement with six heaps of fire-cracked stones, bronze-casting remains as well as human bones in accumulations of firecracked stones and in diffuse stone-settings - there were found no less than eighteen bronze artefacts, of which only one of the artefacts could be linked to human bones and thus be interpreted as a burial. These artefacts included one razor, two double-studs, one knife, one pin and three awls. Hille Jaanusson interprets the objects as belonging to the "settlement layer" (Jaanusson et. al. 1978:19, 27f). As Carlsson emphasizes, Hallunda is probably not an ordinary settlement, and in my opinion it is such a place where I imagine that family members or kinship groups gathered in connection with passage rituals, metamorphoses and transformations of human bodies.

Another aspect to bring up is the occurrence of flint fire-stones in the razor combinations, where the fire may be considered as an expression of and means for enabling metamorphoses and transformations. Knowledge of how to handle the fire and the way in which different fire rituals were conducted may have had significance in connection with transformation rituals for humans, animals and artefacts, as above all the finds from heaps of fire-cracked stones bear witness to. Perhaps the fire was an important part of other passage rituals during the life course before it acquired significance for the last passage or transition, that of death. These aspects may contribute to a broader understanding of places like Hallunda.

One further issue to discuss is how the south to south-west orientation of the razor combinations in the cairns and stone-settings should be perceived. Possibly the southern orientation can be linked to conceptions about which places the living and the dead should inhabit in the landscape and how one journeyed from the world of the living to the world of the dead. Perhaps it is possible to imagine that the dead should inhabit other parts of the cairn than those corresponding to where the living resided in the longhouse. Houses for the living usually have a W-NW to E-SE orientation (Ullén 1995; Borna-Ahlkvist 2002; Victor 2002:57f; Fig. 8) whereas razor combinations have been deposited with a S-SW orientation. Cairns, constructed in the eternal material of stone and designed as a circle, were the home of the dead. Longhouses, built of perishable wood and designed with a linear principle, were the home of the living. 


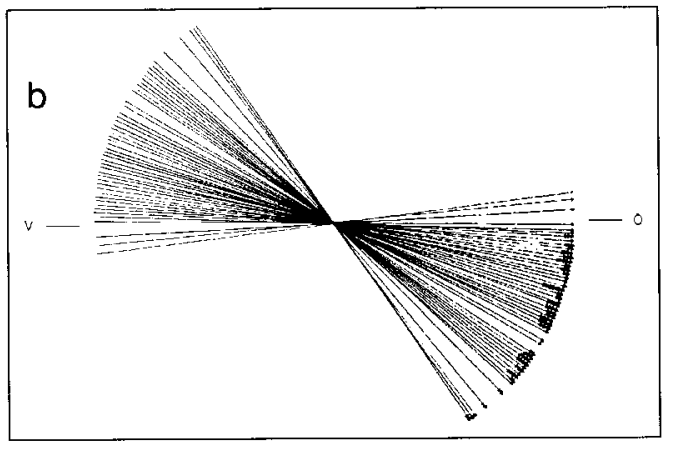

Fig. 8. Orientation of longhouses (Victor 2002:57).

Helena Victor has also shown that houses with stone walls, so-called Brobyhus, are oriented in other directions than the wooden longhouses (Victor 2001:144). Victor interprets the Brobyhus as mortuary houses where the dead were laid before being buried (ibid:183). These houses signified the place of the undead in a phase of liminal transformation, a link with and transition from the features and world of the longhouse to that of the cairn; the Brobyhus had the linear form of a longhouse but were built of stone, the construction material of cairns. To die was probably a process in several stages. The houses can, however, also be given broader meanings as special houses where ritually dead persons in connection with other passage rituals during the life course, for example births, initiations, marriage or widowhood, were symbolically enclosed during the metamorphosis/magnification phase and possibly excluded from the house of the living. The lack of entrances and exits as well as cultural layers in the Brobyhus may then appear as less surprising. Instead the architecture tells us that the purpose was seclusion and enclosure. Part of the rituals might have been to help persons performing the passage ritual to enter (enclosing) and to exit (emerging) from the Brobyhus. The lack of cultural layers may indicate that they were not allowed to eat or cook any food while in the metamorphosis/magnification phase.

\section{LIMINAL PLACES AND LIMINAL PASSAGES}

The aim of this paper has been to discuss a special combination of artefacts, socalled razor combinations, consisting of a razor, a pair of tweezers, a doublestud, a knife blade and occasionally an awl and a flint fire-stone. I imagine that these artefacts should be interpreted as ritual equipment used by persons with special ritual knowledge and wisdom in connection with passage rituals and changes in social roles during the human life course.

With reference to rock paintings in Alta in northern Norway, Knut Helskog (1995:254) has argued that rituals connected with different liminal conditions can be linked to liminal places in the landscape. In the same way I will approach the places in the landscape where cairns and stone-settings have been built; liminal places in the landscape marking boundaries and with reference to various water contexts can be intertwined with liminal phases during the life course. With this view it is possible to link liminal places like mountain ridges, hilltops, points, capes, forelands, islands and narrow water passages with the persons who were buried there, persons with the ritual knowledge and wisdom of how to transform 
humans from one phase in life to another. The increase in razor combinations during period IV-V, especially period $\mathrm{V}$, indicates that more persons could take on these roles and perhaps more significant passage rituals during the life course. This interpretation is in line with the view of the anthropologist Mary Douglas, who argues that control of physical boundaries in a society may be an indication of control of the bodily boundaries (Douglas 1997[1966]). Several boundary places in the landscape could consequently be interpreted as many different kinds of passages, metamorphoses or liminal conditions during the life course. Yet, one important question that has not been asked is why some individuals were buried with razor combinations whereas others were buried with rings or no bronzes at all.

From a perspective of change I imagine that mountain ridges probably were the first places in the landscape to be marked with cairns and stone-settings. In some cairns individuals were buried while other cairns represent boundaries, thresholds or passages. During period III, persons who had knowledge and wisdom of the practices surrounding passage rituals began to be buried together with special ritual equipment. These persons could be both men and women, but regarding age they were probably seen as initiated adults. As time went on, further boundaries in the landscape such as narrow water passages, points, islands and forelands came to be marked by cairns and stone-settings. This could indicate additional passage rituals during the life course, whereby more persons with ritual knowledge and wisdom become visible in burials from the late Bronze Age. On the whole the late Bronze Age is characterized by the fact that more people, from a wider range of social groups but especially children, become visible partly in the cemeteries and burials in heaps of fire-cracked stones (Thedéen 2002b:62ff), and partly at rock-carving places where there are later carving phenomena with images of footprints representing children, adolescents and women (Hauptman Wahlgren 2001:97, 2002:223f). During period VI the ritual traditions change, and razors were formed in new ways and deposited either as single items or together with pins in stone-settings in cemeteries. This implies a change in the meaning of the ritual practices linked to passage rituals.

\section{English revised by Laura Wrang.}

\section{ACKNOWLEDGEMENT}

Thanks to Katty Hauptman Wahlgren and Marie Svedin for critical comments and inspiring thoughts on an earlier draft of this paper. 


\section{REFERENCES}

Almgren, O. 1905. "Kung Björns hög” och andra fornlämningar vid Håga. KVHAA. Stockholm.

Andersson, K. 2001. En hällkista vid Alby i Botkyrka socken, Södermanland. In: Bolin, H., Kaliff, A. \& Zachrisson, T. (Eds). Mellan sten och brons. Uppdragsarkeologi och forskning kring senneolotikum och bronsålder. OPIA 27 \& Stockholm Archaeological Reports No 39. Pp. 74-83.

Artelius, T. 1996. Långfärd och återkomst - skeppet i bronsålderns gravar. Riksantikvarieämbetet. Arkeologiska undersökningar. Skrifter 17. Kungsbacka.

Baudou, E. 1968. Forntida bebyggelse i Angermanlands kustland. Arkeologiska undersökningar av ångermanländska kuströsen. Härnösand.

Bergengren, K. Bronålder, järnålder - några gravfynd. Eskilstuna museer. Pp. 3-9.

Bolin, H. 1999. Kulturlandskapets korsvägar. Mellersta Norrland under de två sista årtusendena $f \mathrm{Kr}$. Stockholm Studies in Archaeology 19. Stockholm.

Borna-Ahlkvist, H. 2002. Hällristarnas hem. Gårdsbebyggelse och struktur i Pryssgården under bronsålder. Riksantikvarieämbetet. Arkeologiska undersökningar. Skrifter 42. Stockholm. Diss.

Bradley, R. 1990. The Passage of Arms. An archaeological analysis of prehistoric hoard and votive deposits. Oxford.

- 1997. Death by Water: Boats and Footprints in the Rock Art of Western Sweden. Oxford Journal of Archaeology 16(3) 1997. Pp. 315-324.

Carlsson, A. 2001. Tolkande arkeologi och svensk forntidshistoria. Bronsåldern. Stockholm Studies in Archaeology 22. Stockholm.

Damell, D. 1971. Rekarne under bronsålder - äldsta järnålder. Uppsala. Lic.

- 1985. Bronsålder i Södermanland. Södermanlands museum. Rapport 7. Nyköping.

Douglas, M. 1997[1966]. Renhet och fara. En analys av begreppen orenande och tabu. Nya Doxa. Nora.

Drakenberg, S. \& Gustawsson, K.A. 1934. Ulleråkers slott. Studier tillägnade Gunnar Ekholm. Uppsala. Pp. 204-218.

Elfstrand, B. 1982. Röse och stensättning från bronsåldern. Riksantikvarieämbetet. Rapport UV 1982:52. Stockholm.

Fagerlund D. \& Hamilton, J. 1995. Annelund - en hällkista och bebyggelse från senneolitikum och bronsålder: Riksantikvarieämbetet. Arkeologiska undersökningar. Uv-Uppsala Rapport 1995:13.

Van Gennep, A. 1960[1909]. The rites of passage. Chicago.

Gilchrist, R. 1999. Gender and Archaeology. Contesting the past. Routledge. London.

- 2000 (Ed). Human Lifecycles. World Archaeology 31:2.

Glob, P.V. 1971. Högarnas folk. Stockholm.

Hauptman Wahlgren, K. 2001. Hällristningstradition och förändring i nordöstra Östergötland. In: Bolin, H., Kaliff, A. \& Zachrisson, T. (Eds). Mellan sten och brons. Uppdragsarkeologi och forskning kring senneolotikum och bronsålder. OPIA 27 \& Stockholm Archaeological Reports No 39. Pp. 88-101.

- 2002. Bilder av betydelse. Bronsålderns hällristningslandskap i nordöstra Östergötland. Stockholm Studies in Archaeology 23. Stockholm. Diss.

Helskog, K. 1995. Maleness and femaleness in the sky and the underworld - and in between. In: Helskog, K. \& Olsen, B. (Eds). Perceiving Rock Art: Social and Political Perspectives. Pp. 247-262. Oslo.

Hemmendorf, O. 1978. Arkeologisk undersökning 1971. Fornlämningarna 18-20, rösen och stensättningar, bronsålder, Botkyrka sn, Södermanland. Riksantikvarieämbetet. Uv Rapport 1978:38. Stockholm.

Hodder, I. 1997. Commentary: the gender screen. In: Moore, J \& Scott, E. (Eds). Invisible People and Processes: Writing Gender and Childhood into European Archaeology. Leicester University press. London. Pp. 75-78.

Hyenstrand, Åke 1966. Igelstakomplexet. Kring yngre bronsålder i Mälarområdet. Uppsala. Lic.

- 1968. Gravformer och symboltecken under yngre bronsålder. Fornvännen 63. Pp. 185-189.

Jaanusson, H. \& Silvén, U. 1962. Undersökningen av Dragbyröset 88. TOR vol VIII. Pp. 5-44.

Jaanusson, H., Löfstrand, L. \& Vahlne, G. 1978. Arkeologisk undersökning 1969-71, Hallunda, Botkyrka sn, Södermanland. III: Fornlämning 69, boplats. Riksantikvarieämbetet UV Rapport 1978:11. Stockholm. 
Jennbert, K. 1992. Changing Customs. Reflections on Grave Gifts, Burial Practices and Burial Rituals during Period III of the Bronze Age in Southeast Scania. Meddelanden frän Lunds universtitets historiska museum 1991-1992. Lund. Pp. 91-103.

- 1993. Släkters hågkomst. Om bruket av bronsålderns gravhögar. In: Larsson, L. (Ed). Bronsålderns gravhögar. Lund. Pp. 69-78.

Jochenhövel, A. 1971. Die Rasiermesser in Mitteleuropa. Prähistorische Bronzefunde. Band 1. Munchen. Johansen, B. 1993. Skärvstenshögar och sörmländsk bronsålder. Arkeologi i Sverige. Ny följd 2. RAÄ. Pp. 99-118. Stockholm.

Johnsen, B \& Welinder, S. 1995 (Eds). Arkeologi om barn. OPIA 10. Uppsala.

Jones, A. 2002. A Biography of Colour: Colour, Material Histories and Personhood in the Early Bronze Age of Britain and Ireland. In: Jones, A. \& Mac Gregor, G. (Eds). Coloring the Past. The Significance of Colour in Archaeological Research. Berg. Pp. 159-174.

Joyce, R. 2000. Girling the girl and boying the boy. World Archaeology 31:2.

Kaul, F. 1998. Ships on Bronzes. A study in Bronze Age religion and iconography. Köpenhamn.

- 1999. I östen stiger solen op. Skalk 1999:5. Pp. 20-30.

Keates, S. 2002. The Flashing Blade. Copper, Colour and Luminosity in North Italian Copper Age Society. In: Jones, A. \& Mac Gregor, G. (Eds). Coloring the Past. The Significance of Colour in Archaeological Research. Berg. Pp. 109-125.

Kristiansen, K. 1983. Kriger og hövding i Danmarks bronzealder. Et bidrag til bronzealdersvaerdets kulturhistorie. In: Stjernqvist, B. (Ed). Struktur och förändring i bronsålderns samhälle. Rapport från det tredje nordiska symposiet för bronsåldersforskning i Lund 23-25 april 1982. University of Lund. Institute of Archaeology. Report series no. 17. Lund. Pp. 63-87.

- 1998. Europe before history. Cambridge University Press. Cambridge. Diss.

- 1999. Symbolic structures and social institutions. The twin rulers in bronze age Europe. In: Gustafsson, A. \& Karlsson, H. (Eds). Glyfer och arkeologiska rum - en vänbok till Jarl Nordbladh. Gotarc Series A vol 3. Göteborg. Pp. 537-552.

La Fontaine, J. S. 1985. Initiation: Ritual Drama and Secret Knowledge across the World. Harmondsworth.

Larsson, T B. 1986. The Bronze Age Metal Work in Southern Sweden. Aspects of Social and Spatial Organization 1800-500 BC. Studia Archaeologica Universitatis Umensis 4. Umeå. Diss.

- 1993. Vistad. Kring en befäst gård i Östergötland och östersjökontakter under yngre bronsålder. Studia Archaeologica Universitetis Umensis 4. Umeå.

- 2002. De döda, de "andra" och djuren. In: Goldhahn, J. (Ed). Bilder av bronsålder. Pp. 91-111.

Lillehammer, G. 1989. A child is born: the child's world in an archaeological perspective. Norwegian Archaeological Review, 22. Pp. 89-105.

Lutkehaus, N. \& Roscoe P. B. (Eds). 1995. Gender Rituals. Female initiation in Melanesia. Routledge. London.

Lincoln, B. 1991. Emerging from the Crystalis: Studies in Rituals of Women's Initiation. Cambridge.

Lundborg, L. 1972. Undersökningar av bronsåldershögar och bronsåldersgravar i södra Halland. Hallands museum, 2. Halmstad.

Moore, J \& Scott, E. (Eds). 1997. Invisible People and Processes: Writing Gender and Childhood into European Archaeology. Leicester University press. London.

Olausson, M. 1995. Det inneslutna rummet - om kultiska hägnader, fornborgar och befästa gårdar I Uppland frän 1300 f Kr till Kristi födelse. Riksantikvarieämbetet. Arkeologiska undersökningar. Skrifter 9. Stockholm.

Oldeberg, A. 1938. En rakkniv från Södermanland med fågelfigurer. Fornvännen. Pp. 117-121.

- 1974-1976. Die ältere metallzeit in Schweden. KVHAA. Stockholm.

Pettersson, A-M. 1982. Skeppssättningar $i$ Rute. En undersökning av sex graver från den yngre bronsåldern. RAGU. Nr. 1982:2.

Roscoe, P. 1995. In the Shadow of the Tambaran: Female Initiation Among the Ndu of the Sepik Basin. In: Lutkehaus, N. \& Roscoe P.B. (Eds). 1995. Gender Rituals. Female initiation in Melanesia. Routledge. London. Pp. 55-82. 
Sofaer Derevenski, J. 1997. Linking age and gender as social variables. Ethnographische-Archäeologische Zeischrift 38. Pp. 485-93.

Sofaer Derevenski, J. (Ed). 2000. Children and Material Culture. Routledge. London.

Strömberg, M. 1975. Bronsålder på Österlen. Ystad.

Svensson, M. 1986. Bronsålderns rakknivar. Opublicerad seminarieuppsats. Lunds universitet. Lund.

Sørensen, M-L Stig. 1997. Reading dress: The Construction of Social Categories and Identities in Bronze Age Europe. Journal of European Archaeology. Vol 5.I. Pp. 93-114.

Thedéen, S. 1999. Kosmologi och rituella landskap i Mälardalens bronsålder. In: Nordström, P. \& Svedin, M. (Eds). Aktuell arkeologi VII. Stockholm. Pp. 119-125.

- 2002a. På resa genom livet och landskapet --tankar kring bronsålderns skeppssymbolik. In: Goldhahn, J.

(Ed). Bilder av bronsålder: Pp. 129-150.

-2002b. Livscykel och landskap. - om bronsåldersrösen och skärvstenshögar i Södermanland. Tidsperspektiv 1-2 2001. Umeå. Pp. 62-82.

Torbrügge, W. 1971. Vor- und Frühgeschichtlische Flussfunde. Bericht der Römisch-Germanischen Kommission 51-52.

Treherne, P. 1995. The warrior's beauty: the masculine body and self-identity in Bronze Age Europe. Journal of European Archaeology 3(1). Pp. 105-144.

Turner, V. 1969. The Ritual Process: Structure and Anti-Structure. Ithaca.

Ullén, I. 1995. The power of case studies. Interpretation of a Late-Bronze-Age settlement in central Sweden. Journal of European Archaeology 1994 2:2. Pp. 249-262.

Victor, H. 2001. Bronsålderns kulthus - ett möte mellan profant och sakralt. In: Bolin, H., Kaliff, A. \& Zachrisson, T. (Eds). Mellan sten och brons. Uppdragsarkeologi och forskning kring senneolotikum och bronsålder. OPIA 27 \& Stockholm Archaeological Reports No 39. Pp. 133-152.

- 2002. Med graven som granne. Om bronsålderns kulthus. Aun 30. Uppsala. Diss.

Welinder, S. 1998. The Cultural Construction of Childhood in Scandinavia, 3500 BC-1350 AD. Current Swedish Archaeology. Vol 6. 1998. Stockholm.

Widholm, D. 1998. Rösen, ristningar och riter: Acta Archaeologica Lundensia. Series Prima in 4. Nr 23. Lund. Diss.

Wigren, S. 1987. Sörmländsk bronsåldersbygd. En studie av tidiga centrumbildningar daterade med termoluminescens. Thesis and Papers in North European Archaeology 16. Stockholms universitet. Stockholm. Diss. 